\title{
Unexpected aspects in the dynamics of horizontal gene transfer of prokaryotes: the impact of outer membrane vesicles
}

\author{
Branko Velimirov (D) C Carmen Ranftler
}

Received: 17 January 2018 / Accepted: 19 June 2018 / Published online: 6 August 2018

(C) The Author(s) 2018

\begin{abstract}
Summary Horizontal gene transfer (HGT) was observed by incubation of an amino acid-deficient strain of Escherichia coli (AB1157) with particles gained from an oligotrophic environment, when all deficiencies were restored with frequencies up to $1.94 \times 10^{-5}$ and no preference for a single marker. Hence, the DNA transfer to the revertant cells was carried out by generalized transduction. Those particles display structural features of outer membrane vesicles (OMVs) but contain high amounts of DNA. Due to a process called serial transduction, the revertant's particles were likewise transferring genetic information to deficient E. coli AB1157 cells. These results indicate a new way of HGT, in which mobilized DNA is transferred in particles from the donor to the recipient. Extracted OMV-associated DNA of known alpha-, and gamma-proteobacterials, Ahrensia kielensis and Pseudoalteromonas marina, respectively, was larger than $30 \mathrm{kbp}$ with all sequences in single copy and identified as prokaryotic sequences. Inserted viral sequences were not found.
\end{abstract}

Keywords Serial transduction - Sequence analysis . E. Coli AB1157 · Ahrensia kielensis · Pseudoalteromonas marina

This short review is cordially dedicated to Prof. Adolf Ellinger. Many of the herein presented data and related conclusions were obtained in co-operation with him, whose serious but often humoristic and occasionally sarcastic approach to scientific problems was always challenging and stimulating at the same time.

\section{B. Velimirov}

Center for Pathobiochemistry and Genetics, Medical

University of Vienna, Währingerstr. 10, 1090 Vienna, Austria

B. Velimirov $(\bowtie) \cdot$ C. Ranftler

Center of Anatomy and Cell Biology, Medical University of

Vienna, Schwarzspanierstr. 5, 1090 Vienna, Austria

branko.velimirov@meduniwien.ac.at
Überraschende Aspekte der Dynamik des horizontalen Gentransfers bei Prokaryoten: Die Wirkung von extrazellulären Membranvesikeln

Zusammenfassung Die Inkubation des aminosäuredefizienten Escherichia-coli-AB1157-Bakteriums mit aus einem oligotrophen Gewässer gewonnenen Partikeln bewies das Vorhandensein eines horizontalen Gentransfers (HGT) durch Herstellung aller Funktionen in Revertantenzellen mit Häufigkeiten bis zu $1,94 \times 10^{-5}$. Da hierbei keiner der Marker bevorzugt übertragen wurde, lag offensichtlich eine generalisierte Transduktion vor. Die entdeckten Partikel wiesen strukturelle Analogien mit Vesikeln der äußeren Bakterienmembran (OMV) auf, jedoch enthielten sie große DNA-Mengen. Durch das Phänomen der seriellen Transduktion waren die aus Revertanten stammenden Partikel wiederum infektiös und übertrugen Erbinformation auf defiziente E.-coli-AB1157Zellen. Diese Ergebnisse lassen auf einen neuen Mechanismus des HGT schließen, bei dem mobilisierte DNA in Partikeln von Spender- auf Empfängerzellen übertragen wird. Die extrahierte DNA aus OMV zweier bekannter $\alpha$ - und $\gamma$-Proteobakterien (Ahrensia kielensis und Pseudoalteromonas marina) war $>30 \mathrm{kbp}$ lang, wobei alle Sequenzen als prokaryotisch identifiziert wurden und nur als Einzelkopie vorlagen. Eingefügte virale Sequenzen wurden nicht gefunden.

Schlüsselwörter Serielle Transduktion · Sequenzanalyse - E. coli AB1157 - Ahrensia kielensis - Pseudoalteromonas marina

\section{Introduction}

Prokaryotes are unique in reacting to environmental alterations by a fast acquisition of essential and suitable genetic characteristics. Genome comparisons re- 
vealed that small 16S rRNA sequence alterations can cause huge differences in the complete gene repertoire. Moreover, even populations of a single $16 \mathrm{~S}$ rRNA species contain numerous genomic varieties [11].

This genetic flexibility of the prokaryotes is based in an advantage of the horizontal gene transfer among bacteria as well as between bacteria and other organisms [26, 30]. Obviously, the fate of the transferred DNA in the recipient cell relies on the nature of the DNA molecule itself-if it lacks an active vegetative origin, it must be integrated into the host genome for stable inheritance. Genetic exchange, therefore, plays a key role in the evolution of prokaryotes. The mechanisms and vectors responsible for the horizontal DNA transfer include:

1. the uptake of free DNA from the environment, i.e. transformation,

2. the transfer of DNA from a bacterial donor cell to a bacterial recipient cell termed conjugation,

3 . the phage-mediated passage of bacterial genes referred to as transduction,

4. gene shuffling by gene transfer agents (GTA), which are unusual bacteriophage-like vehicles of genetic exchange, first discovered in the bacterium Rhodobacter capsulatus [33] containing a random $4.5 \mathrm{~kb}$ fragment of bacterial genomic DNA [46] that can be transferred between cells [3, 22, 23, 45, 47, 51] and finally

5. the formation of DNA bearing membrane vesicles (MVs), also referred to as "outer membrane vesicles" (OMVs) or membrane blebs.

The latter mentioned mechanism of DNA transfer was postulated in the last decade $[20,24,35,38,40,52]$ and was shown to function via formation and shedding of membrane vesicles during growth of Gram-negative bacteria, whereby these membrane vesicles are transporters of genetic information between strains. Remarkably, the phenomenon of generation and detaching of membrane vesicle in Gram-negative bacterial cells is well documented and frequent. Recently [25], the formation of similar vesicles was also recorded for Gram-positive bacteria.

Currently, the interest in OMVs concentrates on the following topics:

- trafficking of cell-cell signals [17], i.e. interspecies communication leading to quorum sensing reaction within the microbial community [32, 34, 41];

- traffic vehicles for the delivery of toxins [16, 21, 36];

- transfer of antibiotic resistance determinants [8, 50];

- utilization as diagnostic tools by clinicians [13];

- delivery of antimicrobial substances [1, 2, 28, 29];

- contribution to innate bacterial defence by absorption of antimicrobial peptides and bacteriophages [31];

- contribution to the dynamics of biofilm formation [43, 44];

- inter-kingdom communication [12, 27, 39].
Another line of interest, which was less emphasized within the frame of the ongoing research, dealt with the transfer of genetic information, namely, uptake of free DNA by bacterial cells via transformasomes $[9,18,19]$ and encapsulation of exogenous DNA by outer membrane vesicles [40] as well as DNA transfer within and between genera [15, 20, 40, 52]. Currently, the magnitude of the OMV driven DNA flux has been rather small, ranging from 3 to $36 \mathrm{kbp}$ [10].

In the present review of own investigations, we provide proof that transferable DNA may be well above $36 \mathrm{kbp}$ within OMVs, that OMV infected cells produce again infectious particles, and we offer information on the restoration of deficiencies within an amino aciddeficient strain of E. coli AB1157.

\section{Materials and methods}

Details on the various methods concerning sample collection, $\mathrm{CsCl}$ density equilibrium centrifugation, bacterial cultures, analytical approaches, transmission electron microscopy and experimental design for gene transfer assays are available in Chiura et al., [7], Velimirov and Hagemann, [49], and Hagemann et al., [14].

\section{Results}

During a number of own ultrastructural pilot studies designed to investigate the formation and growth steps of membrane vesicles in transformed $E$. coli populations, the appearance of DNA bearing OMVs was regularly observed [4-6, 48, 49]. Within the frame of this investigation, we detected OMVs that were of similar morphological appearance as the OMVs so far described in the literature [2, 34, 40] but larger in size (usually above $100 \mathrm{~nm}$ in diameter) and revealing a number of surprising features: they were able to transfer genes to recipient cells with high gene transfer frequencies (Tables 1 and 2), and subsequently the recipient cells produced new OMVs. The DNA in newly produced OMVs had increased in length (up to $350 \mathrm{kbp}$ ) compared to the initially harvested OMVs (40-60 kbp).

In contrast, previously published information on DNA containing OMVs indicated DNA lengths ranging from 3 to $36 \mathrm{kbp}$ [10]. In follow-up studies [7, 49] and during preparatory investigations where we inspected over 1000 TEM slides and investigated whether OMVs within the mentioned size fraction $(>100 \mathrm{~nm}$ in diameter) from natural seawater would trigger the above quoted features in recipient cells, the following traits were recorded for the produced outer membrane vesicles:

1. The observed vesicles appeared already in harvestable quantities before the end of the logarithmic phase of the recipient cell culture but reached their maximum in the stationary phase (Fig. 1). 
Table 1 Gene transfer frequency \pm standard deviation from OMVs derived from $0.2 \mu \mathrm{m}$ filtered seawater concentrate to $E$. coli AB1157 designated as "reverted" at 4 different MOls and corresponding control experiments. $n=6$

\begin{tabular}{|c|c|c|c|c|c|c|}
\hline & MOI & 0.12 & 1.0 & 5.1 & 20 & 200 \\
\hline \multirow[t]{5}{*}{ Experiment } & All amino acids reverted & 0 & 0 & $1.39 \times 10^{-7}$ & $1.46 \times 10^{-5}$ & $1.94 \times 10^{-5}$ \\
\hline & Leu reverted & $4.41 \pm 3.04 \times 10^{-6}$ & $3.33 \pm 3.22 \times 10^{-5}$ & $9.04 \pm 2.85 \times 10^{-3}$ & $1.04 \pm 1.62 \times 10^{-3}$ & $7.34 \pm 3.04 \times 10^{-4}$ \\
\hline & Pro reverted & $5.73 \pm 2.82 \times 10^{-6}$ & $2.22 \pm 2.38 \times 10^{-5}$ & $8.34 \pm 2.38 \times 10^{-3}$ & $7.42 \pm 1.12 \times 10^{-3}$ & $7.15 \pm 0.28 \times 10^{-5}$ \\
\hline & His reverted & $3.53 \pm 0.92 \times 10^{-6}$ & $7.41 \pm 1.76 \times 10^{-5}$ & $9.04 \pm 3.07 \times 10^{-3}$ & $9.83 \pm 3.88 \times 10^{-3}$ & $7.34 \pm 4.13 \times 10^{-4}$ \\
\hline & Arg reverted & $3.09 \pm 0.88 \times 10^{-6}$ & $1.48 \pm 0.52 \times 10^{-5}$ & $9.73 \pm 1.90 \times 10^{-3}$ & $6.03 \pm 0.92 \times 10^{-3}$ & $5.83 \pm 1.08 \times 10^{-4}$ \\
\hline \multirow[t]{2}{*}{ Control } & $\begin{array}{l}\text { MVs + UV } \pm A B 1157 \\
\text { MVs aut. + AB1157 } \\
\text { MVs aut./untr. } \pm A B 1157\end{array}$ & 0 & 0 & 0 & 0 & 0 \\
\hline & $\begin{array}{l}\text { Davis buffer }+A B 1157 \text { or } \\
\text { UC supernat. }+ \text { AB1157 }\end{array}$ & 0 & 0 & 0 & 0 & 0 \\
\hline
\end{tabular}

Table 2 Gene transfer frequency \pm standard deviation from OMVs derived from transductant colonies (F1) to E. coli AB1157 designated as "reverted" at a $\mathrm{MOI}$ of 5.5 and corresponding control experiments

\begin{tabular}{|c|c|c|c|c|c|c|}
\hline & & $\begin{array}{l}\text { All amino acids } \\
\text { reverted }\end{array}$ & Leu reverted & Pro reverted & His reverted & Arg reverted \\
\hline Experiment & Transcolonies & $2.0 \pm 1.3 \times 10^{-6}$ & $12.3 \pm 18.1 \times 10^{-6}$ & $8.77 \pm 8.74 \times 10^{-6}$ & $3.16 \pm 0.65 \times 10^{-6}$ & $12.0 \pm 1.9 \times 10^{-6}$ \\
\hline \multirow[t]{2}{*}{ Control } & $\begin{array}{l}\text { MVs + UV } \pm A B 1157 \\
\text { MVs aut. + AB1157 } \\
\text { MVs aut./untr. } \pm \text { AB1157 }\end{array}$ & 0 & 0 & 0 & 0 & 0 \\
\hline & $\begin{array}{l}\text { Davis buffer }+A B 1157 \text { or } \\
\text { UC supernat. }+A B 1157\end{array}$ & 0 & 0 & 0 & 0 & 0 \\
\hline
\end{tabular}

2. The investigated particles were DNA carrying OMVs.

3. The packaged DNA ranged from 50 to $80 \mathrm{kbp}$.

4. First sequencing data pointed out that the vesicle DNA consisted of bacterial DNA.

5. The number of visible MVs (burst size) within the cells was low, ranging between 1 and 5 per bacterial cell.

6. The OMVs were released by budding (Fig. 2).

7. The observed vesicles infected other bacterial cells and repaired genetic deficiencies (Table 1). It could be repeatedly shown that the incubation of cells belonging to the amino acid-deficient strain of $E$. coli $\mathrm{AB} 1157$ with membrane vesicles revealed evidence of HGT by restoration of all deficiencies (markers) in revertant cells with frequencies between $1.39 \times 10^{-7}$ for a multiplicity of infection (MOI) of 5.1 to $1.46 \times 10^{-5}$ for a MOI of 20 . The highest gene transfer frequency was obtained for single markers with values up to $1.04 \times 10^{-2}$ at a MOI of 20 . These obtained gene transfer frequencies belong to the highest reported frequencies and only the values recorded by McDaniel [37] were higher than those obtained from our investigations.

8. This horizontal gene transfer between species has all characteristics of a generalized transduction [42] as none of the markers was preferentially transferred.

9. Obtained transductants were able to produce new infective vesicles that were again released via budding. These vesicles were of larger size than the primary infecting vesicles. The observed process of consecutive infection was termed serial transduction and the DNA of the resulting OMVs can reach a length of about $350 \mathrm{kbp}$.

10. Investigations with the transmission electron microscope (TEM) of experimentally infected E. coli cells revealed the appearance of distinct electron dense structures and bodies (EDB), which had never been observed until now (Fig. 3a,b,c), considered as precursors of budding membrane vesicles (Fig. 3d).

11. The OMVs, mostly derived from alpha-proteobacteria, were also able to infect phylogenetically distant bacterial species such as gamma-proteobacteria (E. coli $\mathrm{AB} 1157)$ and induce intergeneric transduction, thus functioning as gene mediators for a broad host range.

Using TEM in a different approach, inspected OMVs from the alpha-proteobacterium Ahrensia kielensis and from Pseudoalteromonas marina, a gamma-proteobacterium, revealed two kinds of vesicular bodies: a bilayered form of OMVs with diameters between 30 and $250 \mathrm{~nm}$, but also OMVs exhibiting double bilayers and diameters ranging between 80 and $200 \mathrm{~nm}$. While the bilayered OMVs could be distinguished either by a large electron-dense structure or were electron translucent, the double bilayered ones showed the electron dense substance in contrast in the core region within the intermembrane space of the first and second bilayer (Figs. 1 and 3 ). 
Fig. 1 Membrane vesicles (MVs) produced from a Pseudoalteromonas marina and $\mathbf{b}$ Ahrensia kielenis during the stationary phase
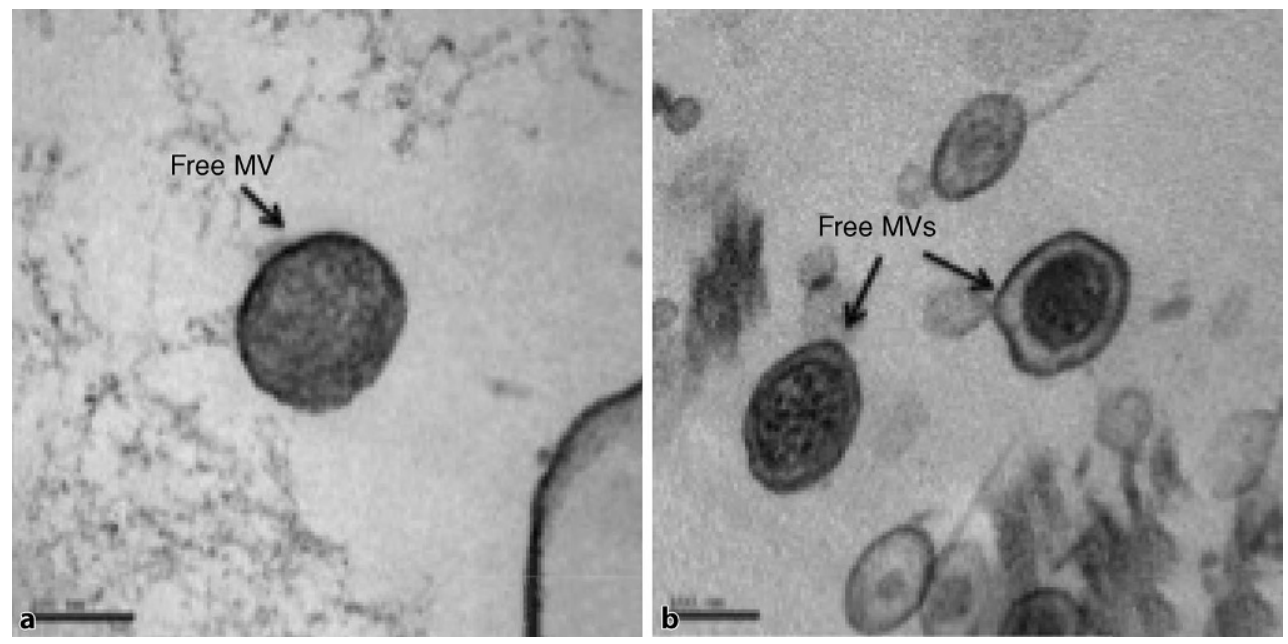

Fig. 2 Membrane vesicle (MV) production: a Negative stained total view of a bacterial cell in the process of budding. $\mathbf{b}$ Ultrathin section of bacterial cells in the process of budding
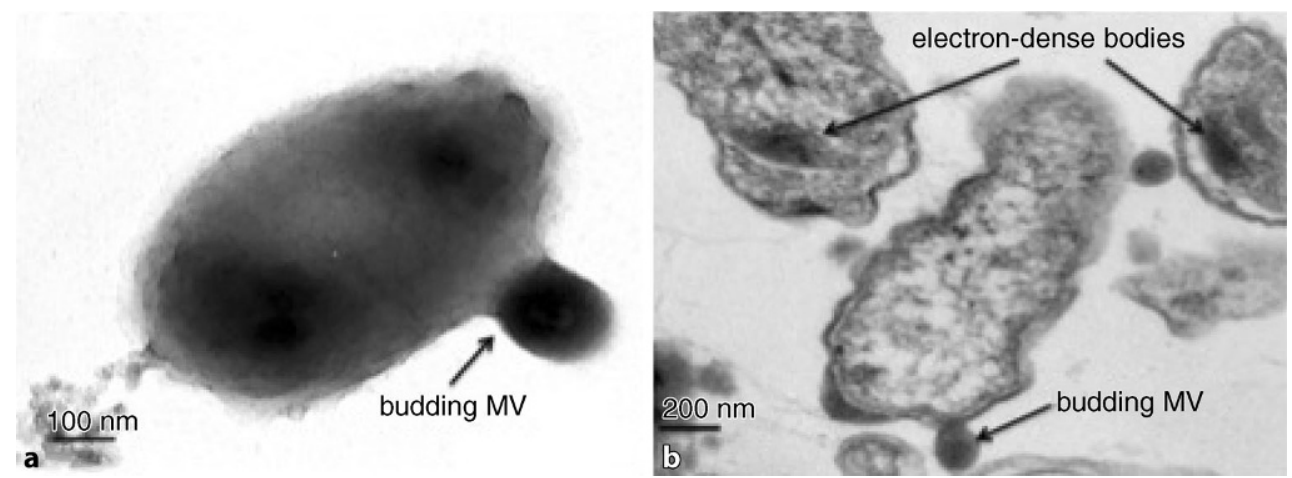

Furthermore, 30,094 bp of the genome from OMVs of A. kielensis and 45,981 bp of P. marina were sequenced. The findings pointed out that the sequences existed only in single copy and, except for one, had prokaryotic equivalences. Inserted viral sequences were not detected. We found no hint in the OMVs under investigation for any OMV-specific genomes. Some of the analyzed sequences code for proteins which are membrane associated like extracellular solute-binding protein family 3 , TonB family protein, TonB-dependent receptor protein, and ABC transporter permease. It should be noted that proteins involved in defence and survival strategy (e.g. the putative TetR family transcriptional regulator or the toxin-antitoxin system, toxin component, RelE family) were detected.

\section{Discussion}

Although the OMV-DNA complex is a subject of great interest and hence profoundly under investigation, unexpectedly less is known about sequence information. In this short review we show that our investigation [14] was the first to report that the DNA incorporated in bacterial OMVs contains a large spectrum of protein coding sequences. These DNA sequences are either encapsulated in regular bilayered membrane vesicles which originate from the outer membrane of the bacterium or in the more difficult design of the OMV double bilayer types consisting of a further inner membrane layer being probably derived from the cytoplasmic cell membrane. Electron dense structures (EDS) analog to those shown in thin sections (Figs. 2 and 3) were also monitored in prior studies of revertant E. coli strains in liquid culture during OMV production [7]. In these earlier investigations, gold-labelled anti-DNA antibodies bound to likewise electron dense structures were used, which we named electron dense bodies (EDBs), thereby demonstrating the presence of DNA in these EDBs. Despite our finding of a clear analogy in our TEM slides to our previous results, we decided to refrain from presuming that DNA is necessarily a fraction or a part of the EDBs in thin sections of A. kielensis or P. marina while attempting to find precursor structures for the OMVs. As bacterial DNA fibers are often but not always associated with polyphosphate bodies, which have a similar electron dense appearance as the observed EDBs, we could not verify that all the detected EDBs were precursor structures for the DNA to be encapsulated in OMVs prior to budding. Nonetheless, it was assumed that the majority of these structures were precursors as a distinct granulation in the DNA carrying EDBs was regularly observed, which was absent in polyphosphate bodies.

The described process of horizontal gene transfer via OMVs leads to a number of assumptions, which 
Fig. 3 Thin sections of transductants, demonstrating the structure of electron dense bodies (EDBs). a EDBs of different electron densities and sizes. b Higher magnification of an EDB in the vicinity of an electron dense network (EDN) within the recipient cell. c EDB in contact with the inner layer of the cell membrane. d Budding structure displaying features of a double membraned vesicle
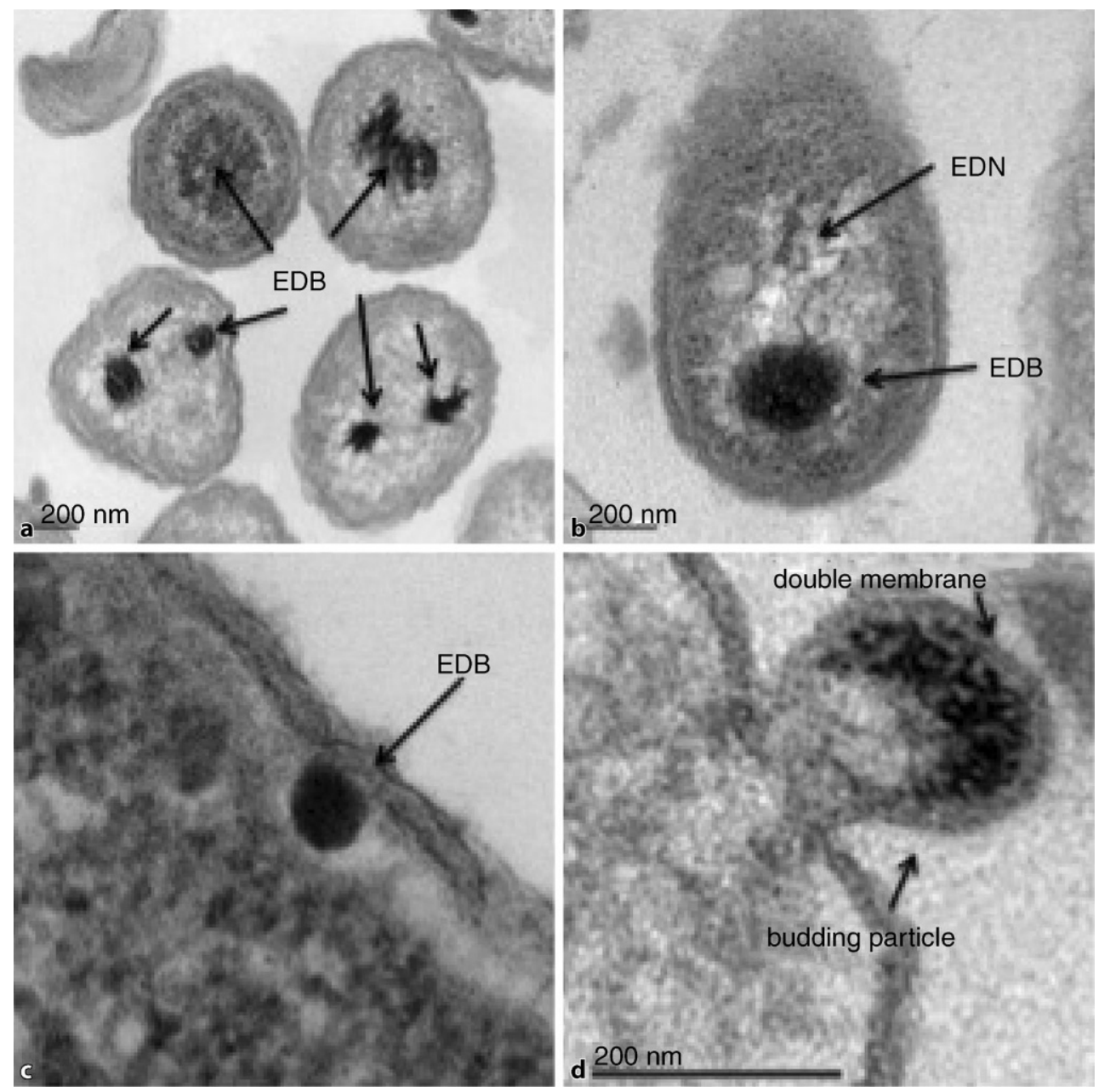

need to be mentioned. The finding of restored functions of all markers in revertant cells at MOIs of 5, 20, and 200, demonstrates that multiple infections may have taken place. At the present state of knowledge, one can only presume the possible effects of the noted gene transfer strategy on bacterial populations. Burst size, which can be equated with budding size, indicates that the abundance of OMVs may well be below that of surrounding bacteriophages. Nonetheless, all our investigations suggest that OMVs are by far more efficient in transferring genes than bacteriophages.

A surprising feature of the investigations was that the result of this HGT are revertants, which produce themselves anew infectious OMVs with increased DNA length, reaching a DNA content of $>350 \mathrm{kbp}$.

All so far listed features of the investigated OMVs, namely release via budding, particle-related transfer of large amounts of DNA to recipient cells and their potential for serial gene transfer, show that we observed an important and new mechanism for HGT between prokaryotic cells. Furthermore, the production of OMVs may be a strategy to ensure a back-up of genetic information in case of nutrient shortage leading to starvation of bacterial populations. Assuming that transfected bacterial cells produce some $350 \mathrm{kbp}$ per OMV in the stationary phase and that each particle carries a unique piece of the E. coli chromosome, then 13-20 of such OMVs would be sufficient to save the entire bacterial chromosome. To which extent the knowledge about the functions of OMVs and associated DNA may be used for medical applications, e.g. to support DNA repair in preventing carcinogenesis, remains a matter of debate and experimentation in the future.

Funding Open access funding provided by Medical University of Vienna.

Conflict of interest B. Velimirov and C. Ranftler declare that they have no conflict of interest.

Open Access This article is distributed under the terms of the Creative Commons Attribution 4.0 International License (http://creativecommons.org/licenses/by/4.0/), which permits unrestricted use, distribution, and reproduction in any medium, provided you give appropriate credit to the original author(s) and the source, provide a link to the Creative Commons license, and indicate if changes were made. 


\section{References}

1. Beveridge TJ. Structures of gram-negative cell walls and their derived membrane vesicles. J Bacteriol. 1999;181:4725-33.

2. Beveridge TJ, Makin SA, Kadurugamuwa JL, Li Z. Interactions between biofilms and the environment. FEMS Microbiol Rev. 1997;20:291-303.

3. Biers JB, Wang K, Pennington C, Belas R, Chen F, Moran MA. Occurrence and expression of gene transfer agent genes in marine bacterioplankton. ApplEnviron Microbiol. 2008;74:2933-9.

4. Chiura HX, Kato K, Takagi J. Phage-like particles released by a marine bacterium. Wien Mitt. 1995;128:149-57.

5. Chiura HX, Velimirov B, Kogure K. Virus-like particles in microbial population control and horizontal gene transfer in aquatic environments. In: Bell CR, Brylinsky M, JohnsonGreen P, editors. Microbial Biosystems: New Frontiers. Proceedings of the 8th International Symposium on Microbial Ecology, Atlantic Canada Society for Microbial Ecology; Halifax. 2000. pp. 167-73.

6. Chiura HX, Yamamoto H, Koketsu D, Naito H, Kato K. Viruslike particle derived from a bacterium belonging to the oldest lineage of the domain bacteria. Microbes Environ. 2002;17:48-52.

7. Chiura HX, Kogure K, Hagemann S, Ellinger A, Velimirov B. Evidence for particle induced gene transfer and serial transduction between bacteria. FEMS Microbiol Ecol. 2011;76:576-91.

8. Ciofu O, Beveridge TJ, Kadurugamuwa J, Walther-Rasmussen J, Hoiby N. Chromosomal beta-lactamase is packaged into membrane vesicles and secreted from Pseudomonas aeruginosa. J Antimicrob Chemother. 2000;45:9-13.

9. Deich RA, Hoyer LC. Generation and release of DNA-binding vesicles by Haemophilus influenza during induction and loss of competence. J Bacteriol. 1982;152:855-64.

10. Dorward DW, Garon CF, Judd RC. Export and intercellular transfer of DNA via membrane blebs of Neisseria gonorrhoeae. JBacteriol. 1989;171:2499-505.

11. Francino PM. Gene survival in emergent genomes. In: Horizontal gene transfer in microorganisms. Norfolk: Caister Academic Press; 2012. pp. 1-12.

12. GoedhartJ, Rohrig H, HinkMA, van HoekA, Visser AJ, BisselingT, Gadelle TWJr.. Nodfactors integrate spontaneouslyin biomembranes and transfer rapidly between membranes and to root hairs, but transbilayer flip-flop does not occur. Biochemistry. 1999;38:10898-907.

13. György B, Szabo TG, Pasztoi M, Pal Z, Misjak P, Aradi B, Laszlo V, Pallinger E, Pap E, Kittel A, Nagy G, Falus A, Buzas EI. Membrane vesicles, current state-of-art: emerging role of extracellular vesicles. Cell Mol Life Sci. 2011;68:2667-88.

14. Hagemann S, Stöger L, Kappelmann M, Hassl I, Ellinger A, Velimirov B. DNA-bearing membrane vesicles produced by Ahrensia kielensis and Pseudoalteromonas marina. J Basic Microbiol. 2013;53:1-11.

15. Hertwig S, Popp A, Freytag B, Lurz R, Appel B. Generalized transduction of small Yersinia enterocolitica plasmids. Appl Environ Microbiol. 1999;65:3862-6.

16. Kadurugamuwa JL, Beveridge TJ. Virulence factors are released from Pseudomonas aeruginosain association with membrane vesicles during normal growth and exposure to gentamicin: A novel mechanism of enzyme secretion. JBacteriol. 1995;177:3998-4008.

17. Kadurugamuwa JL, Beveridge TJ. Membrane vesicles derived from Pseudomonas aeruginosa and Shigella flexneri can be integrated into the surfaces of other Gram-negative bacteria. Microbiology. 1999;145:2051-60.

18. Kahn ME, Maul G, Goodgal SH. Possible mechanism for donor DNA binding and transport in Haemophilus. Proc Natl Acad Sci Usa. 1982;79:6370-4.

19. Kahn ME, Barny F, Hamilton OS. Transformasomes: specialized membranous structures that protect DNA during Haemophilus transformation. Proc Natl Acad Sci Usa. 1983;80:6297-931.

20. Kolling GL, Matthews KR. Export of virulence genes and Shiga toxin by membrane vesicles of Escherichia coli O157:H7. ApplEnviron Microbiol. 1999;65:1843-8.

21. Kuehn MJ, Kesty NC. Bacterial outer membrane vesicles and the host-pathogen interaction. Genes Dev. 2005;19:2645-55.

22. Lang AS, Beatty JT. Genetic analysis of a bacterial genetic exchange element: the gene transfer agent of Rhodopseudomonas capsulata. Proc Natl Acad Sci Usa. 2000;97:859-64.

23. Lang AS, Beatty JT. A bacterial signal transduction system controls genetic exchange and motility. J Bacteriol. 2002;184:913-8.

24. Lee E-Y, Chol D-S, Kim K-P, Gho YS. Proteomics in Gramnegative bacterial outer membrane vesicles. Mass Spectrom Rev. 2008;27:535-55.

25. Lee E-Y, Choi D-Y, Kim D-K, Kim JW, Park JO, Kim S, Kim S-H, Desiderio DM, Kim Y-K, Kim K-P, Gho YS. Grampositive bacteria produce membrane vesicles: proteomicsbased characterization of Staphylococcus aureus-derived membranevesicles. Proteomics. 2009;9:5425-36.

26. Lengler JW, Drews G, Schlegel HG. Biology of the prokaryotes. Stuttgart: Thieme; 1999. p. 955.

27. LerougeP, RocheP, FaucherC, MailletF, TruchetG,PromeJC, Denarie J. Symbiotic host-specificity of Rhizobium meliloti is determined by a sulphated and acylated glucosamine oligosaccharide signal. Nature. 1990;344:781-4.

28. Li Z, Clarke A, Beveridge TJ. A major autolysin of Pseudomonas aeruginosa: subcellular distribution, potential role in cell growth and division and secretion in surface membrane vesicles. J Bacteriol. 1996;178:2479-88.

29. Li Z, Clarke A, Beveridge TJ. Gram-negative bacteria produce membrane vesicles which are capable of killing other bacteria. JBacteriol. 1998;180:5478-83.

30. Madigan MT, Martinko JM, Parker J. Microbiology. Upper Saddle River: Prentice Hall; 2000.

31. Manning AJ, Kuehn MJ. Contribution of bacterial outer membrane vesicles to innate bacterial defense. BMC Microbiol. 2011;11:258.

32. Marketon MM, Gronquist MR, Eberhard A, Gonzalez JE. Characterization of the Sinorhizobium meliloti sinR/sinl locus and the production of novel $\mathrm{N}$-acyl homoserine lactones. J Bacteriol. 2002;184:5686-95.

33. Marrs B. Genetic recombination in Rhodopseudomonas capsulata. Proc Natl Acad Sci Usa. 1974;71:971-3.

34. Mashburn LM, Whiteley M. Membrane vesicles traffic signals and facilitate group activities in a prokaryote. Nature. 2005;437:422-5.

35. Mashburn-Warren LM, Whiteley M. Special delivery: vesicle trafficking in prokaryotes. Mol Microbiol. 2006;61:839-46.

36. McBroom A, Kuehn MJ. Outer membrane vesicles. In: Curtiss R III, et al., editor. EcoSal-Escherichia coli and Salmonella: Cellular and Molecular Biology. Washington, DC:ASM Press; 2005.

37. McDaniel LD, Young E, Delaney J, Ruhnau F, Ritchie KB, Paul JH. High frequency of horizontal gene transfer in the oceans. Science. 2010;330:50. 
38. NevotM,DeronceléV, Messner P, GuineaJ, MercadéE.Characterization of outer membrane vesicles released by the psychrotolerant bacterium Pseudoalteromonas antarctica $\mathrm{NF}_{3}$. Environ Microbiol. 2006;8:1523-33.

39. Price NP, Relic B, Talmont F, Lewin A, Promé D, Pueppke SG, Maillet F, Dénarié J, Promé JC, Broughton WJ. Broadhost-Range Rhizobium species strain NGR234 secretes a family of carbamoylated, and fucosylated, nodulation signals that are $\mathrm{O}$-acetylated or sulphated. Mol Microbiol. 1992;6:3575-85.

40. Renelli M, Matias V, Lo RY, Beveridge TJ. DNA-containing membrane vesicles of Pseudomonas aeruginosa PAO1 and their genetic transformation potential. Microbiology. 2004;150:2161-9.

41. Schaefer AL, Taylor TA, Beatty JT, Greenberg EP. Longchain acyl-homoserine lactone quorum sensing regulation of Rhodobacter capsulatus gene transfer agent production. JBacteriol. 2002;184:6515-21.

42. Schicklmaier P, Schmieger H. Frequency of generalised transducing phagesin natural isolates of the Salmonella typhimurium complex. Appl Environ Microbiol. 1995;61:1637-40.

43. Schooling SR, Beveridge TJ. Membrane vesicles: an overlooked component of the matrices of biofilms. J Bacteriol. 2006;188:5945-6957.

44. Schooling SR, Hubley A, Beveridge TJ. Interactions of DNA with biofilm derived membrane vesicles. J Bacteriol. 2009;191:4097-102.
45. Solioz M, Yen HC, Marrs B. Release and uptake of gene transfer agent by Rhodopseudomonas capsulata. J Bacteriol. 1975;123:651-7.

46. Solioz M, Marrs B. Gene transfer agent of Rhodopseudomonas capsulata-purification and characterization of its nucleic acid. Arch Biochem Biophys. 1977;181:300-7.

47. Stanton TB. Prophage-like gene transfer agents - novel mechanisms of gene exchange for Methanococcus, Desulfovibriio, Brachyspira, and Rhodobacter species. Ananerobe. 2007;13:43-9.

48. Velimirov B, Chiura HX, Kogure K. New transducing particles in the sea or are we still missing the essential. In: Ceh M, Drazic G, FidlerS, editors. 7th Multinational Congress on MicroscopyPortoroz. 2005. pp. 249-50.

49. Velimirov B, Hagemann S. Mobilizable bacterial DNA packaged into membrane vesicles induces serial transduction. Mob GenetElements. 2011;1:80-1.

50. Wai SN, Lindmark B, Söderblom T, Takada A, Westermark M, Oscarsson J, Jass J, Richter-Dahlfors A, Mizunoe Y, Uhlin BE. Vesicle-mediated export and assembly of poreforming oligomers of the entobacterial ClyA cytotoxin. Cell. 2003;115:25-35.

51. Wall JD, Weaver PF, Gest H. Genetic transfer of nitrogenasehydrogenase activity in Rhodopseudomonas capsulata. Nature. 1975;258:630-1.

52. Yaron S, Kolling GL, Simon L, Matthews KR. Vesicle mediated transfer of virulence genes from Escherichia coli O157:H7 to other enteric bacteria. Appl Environ Microbiol. 2000;66:4414-20. 